М.О. Корнєєва,

кандидат біологічних наук,

\title{
М.М. Ненька,
}

aсnірант

Інститут біоенергетичних культур і цукрових буряків НАAН

\section{Реакція простих стерильних гібридів буряку цукрового zа zбором цукру на регульовані $\oint$ бактори середовища}

За даними літератури, в процесі селекції відмічено зростання відгуку селекційних матеріалів на регульовані і зниження на нерегульовані фактори середовища. У дослідженні вивчалась експресія комбінаційної здатності компонентів простих стерильних гібридів як материнських компонентів на різне поєднання факторів сортовипробування. Випробовували топкросні гібриди від схрещування п'яти ЧС ліній і п'яти закріплювачів стерильності на звичайному і підвищеному фонах мінерального удобрення у варіантах зі звичайною та розширеною площами живлення. Встановлено модифікувальний вплив факторів сортовипробування на збір цукру. За ефектами комбінаційної здатності вивчено специфічність реакції кожного з генотипів на регульовані фактори середовища, встановлено частки генотипної варіації та зміну співвідношення ї̈ складових на ознаку «збір иукру». Генотипні особливості селекційних ліній найповніше розкриваються за розширеної площі живлення. Виділено кращі гібридні комбінацї̈ з високим ступенем ознаки на рівні фенотипу.

\section{Ключові слова:}

буряк цукровий, урожайність буряку цукрового, цукристість буряку цукрового, збір цукру, розширена площа живлення буряку цукрового, гібрид буряку цукрового.

3бір цукру - важливий показник, залежний від врожайності та цукристості, що контролюються полігенно, і $\epsilon$ наслідком їхньої взаємодії, а також значною мірою підпадає під уплив середовища. А.В. Кільчевський та Л.В. Хотильова вказували на те, що у селекції, відмінно від еволюції, рушійні форми переважають стабілізуючі, які зумовлюють зростання реакції на регульовані фактори та падіння стійкості на нерегульовані фактори середовища [1]. У зв'язку з тим, що сучасним напрямом селекції $\epsilon$ створення генотипів, адекватних певним технологіям, тобто "low input variety high input variety" - сортів 3 низьким і високим енерговне- сенням у технологію, важливим елементом у селекційному процесі став добір стабільних у своєму прояві ліній на аналізуючих фонах [2]. Створення та застосування таких агрофонів у селекційній практиці в культурі буряку цукрового належить вітчизняним ученим А.Л. Мазлумову та М.С. Грицику $[3,4]$.

Матеріали та методика досліджень. Досліди проводилися на Верхняцькій ДСС у 20112012 рр. До створення простих стерильних гібридів було залучено п'ять закріплювачів стерильності (3С) і п'ять чоловічостерильних ліній (ЧС). Стерильність і однонасінність ЧС ліній перевірена за загальноприйнятою методикою [5], причому відбирали лінії з однонасінніс- тю $98-100 \%$ і стерильністю на рівні 97-99\%.

Схрещування проводилося на ділянках вільного перезапилення 3 достатньою ізоляцією по типу топкрос з решіткою $5 \times 5$ [6]. Отримано 20 гібридних комбінацій зі стерильним пилком, які будуть використовуватись як материнський компонент ЧС гібридів буряку цукрового.

Сортовипробування проводилося на звичайному (ЗФ) та підвищеному (ПФ) фонах мінерального живлення, а площа живлення однієї рослини використовувалась у двох варіантах: звичайній (ЗП) $-45 \times 22,5\left(\mathrm{~cm}^{2}\right)$ і розширеній (РП) $45 \times 45\left(\mathrm{~cm}^{2}\right)$ [7]. Отже, регульованими факторами середовища за вивчен- 
Реакція простих стерильних гібридів буряку цукрового за збором цукру на регульовані фактори середовища

ня специфічних реакцій генотипу материнського компонента у формі простих стерильних гібридів були: ЗФЗП (звичайний фон звичайна площа), ЗФРП (звичайний фон розширена площа), ПФЗП (підвищений фон звичайна площа) і ПФРП (підвищений фон розширена площа).

Комбінаційна здатність компонентів простих стерильних гібридів оцінювалася за методикою В.Г. Вольфа та П.П. Літуна [8], а дисперсійний аналіз за Б.О. Доспєховим [9].

Результати досліджень та ïх обговорення. Під упливом регульованих факторів середовища комбінаційна здатність досліджуваних компонентів проявляла мінливість.

Звичайний фон звичайна площа. Гібриди (як материнська форма) у цьому середовищі виразно відрізнялися між собою $\mathrm{F}_{\text {факт }}=6,87>\mathrm{F}_{\text {теор }}=2,01$. За компонентами простих стерильних гібридів відмінності були теж істотними: для 3КЗ ЧС ліній $\mathrm{F}_{\text {факт }}=11,18>\mathrm{F}_{\text {теор }}=2,65$, О типів $\mathrm{F}_{\text {факт }}=7,04>\mathrm{F}_{\text {теор }}=2,92$ і для їх взаємОдії $\mathrm{F}_{\text {факт }}=5,38>\mathrm{F}_{\text {теор }}=2,09$.

Внесок простих стерильних гібридів різнився (рис. 1). Частка впливу генотипу ЧС ліній на мінливість ознаки "збір цукру" була майже вдвічі більшою, ніж О типів і становила 34,3\% проти 16,2\%. Унесок взаємодії компонентів характеризувався найвищим серед джерел варіювання і становив 49,5\% від генотипної варіації ознаки.

Істотні відмінності між компонентами гібридизації дали змогу установити рівень комбінаційної здатності (3К3 і СК3) кожного з них (табл. 1).

3 таблиці 1 видно, що значно високу ЗКЗ за збором цукру проявили дві ЧС лінії -

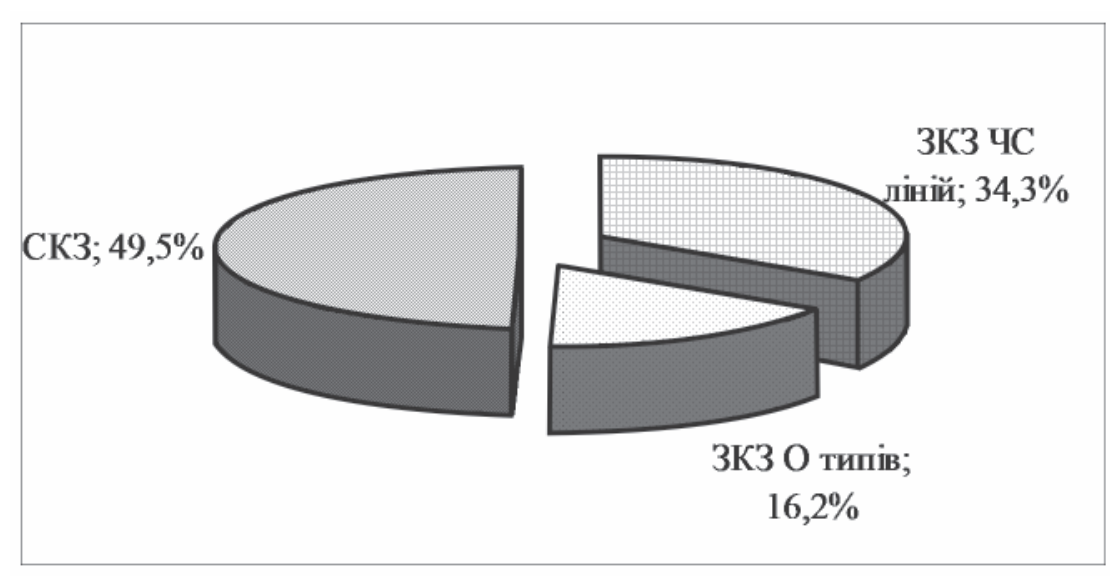

Рис. 1. Частки генотипної варіації компонентів простих стерильних гібридів і їх взаємодії, ЗФЗП

Таблиця 1

Ефекти ЗКЗ і СКЗ за збором цукру ЧС ліній і О типів, ЗФЗП

\begin{tabular}{|c|c|c|c|c|c|c|}
\hline \multirow[t]{2}{*}{ ЧС лінії } & \multirow{2}{*}{$\begin{array}{c}\text { Ефекти } \\
\text { ЗКЗ ЧС } \\
\text { ліній }\end{array}$} & \multicolumn{5}{|c|}{ Ефекти СКЗ } \\
\hline & & От 1 & От 2 & От 3 & От 4 & От 5 \\
\hline ЧС 1 & 0,27 & \# & $-0,10$ & $-0,25$ & 0,58 & $-0,23$ \\
\hline पС 2 & $-0,25$ & $0,82^{*}$ & \# & $-0,43$ & 0,63 & $-1,02^{*}$ \\
\hline 403 & $0,48^{*}$ & 0,25 & $1,00^{*}$ & \# & $-1,27^{\star}$ & 0,02 \\
\hline पС 4 & $-0,95^{*}$ & $-0,92^{*}$ & $-0,33$ & $-0,17$ & \# & $1,42^{*}$ \\
\hline $4 C 5$ & $0,45^{*}$ & $-0,05$ & 0 & 0,23 & $-0,18$ & $\#$ \\
\hline
\end{tabular}

* - достовірно високі ефекти комбінаційної здатності на 5\% рівні значущості.

ЧС $3\left(+0,48^{\star}\right)$ та ЧС $5\left(+0,45^{\star}\right)$. Лінія ЧС 1 характеризувалася позитивним $(+0,27)$, але неістотно доведеним ефектом 3К3, відносно добре вона комбінувалася 3 От $4(+0,58)$. Лінія ЧС 3 проявила один 3 найвищих ефектів взаємодії $\left(+1,00^{*}\right)$ 3 От 2. Лінія ЧС 4 з От 5 за сумою ефектів неадитивної взаємодії алельних генів переважала над усіма 20-ти гібридними комбінаціями, що досліджувались $($ СКЗ $=1,42 *)$.

Звичайний фон розширена площа. У цілому вплив генотипу гібридів у варіанті ЗФЗП оцінювався у 77,0\%, тоді як на розширеній площі він виявився більшим і становив 92,4\% (рис. 2). Це свідчить про те, що фактор "розширена площа живлення" дає можливість ліпше проявитися генотипним особливостям кожної гібридної комбінації.

Між генотипами гібридів були суттєві відмінності: $\mathrm{F}_{\text {факт }}=24,58>\mathrm{F}_{\text {теор }}=2,01$.

Дисперсійний аналіз даних показав, що між компонентами ПСГ, а також їхньою взаємодією існують достовірні відмінності: $\mathrm{F}_{\text {факт }}=47,94>\mathrm{F}_{\text {теор }}=2,69$ (для ЧСліній); $F_{\text {факт }}=21,43>F_{\text {теор }}=21,43$ (для O типів); $\quad \mathrm{F}_{\text {факт }}=17,54>\mathrm{F}_{\text {теор }}=2,09$ (для їхньої взаємодії). Це дало змогу оцінити внесок кожного 3 компонентів у генотипну варіацію ознаки «збір цукру» (рис. 3).

Диференціація компонентів за ефектами комбінаційної здатності показала деяке зміщення оцінок залежно від дії фактора "розширена площа живлення". Так, лінія ЧС 1 характеризувалася істотно високою $3 \mathrm{~K} 3\left(+1,23^{*}\right)$, а лінія 
Реакція простих стерильних гібридів буряку цукрового за збором цукру на регульовані фактори середовища

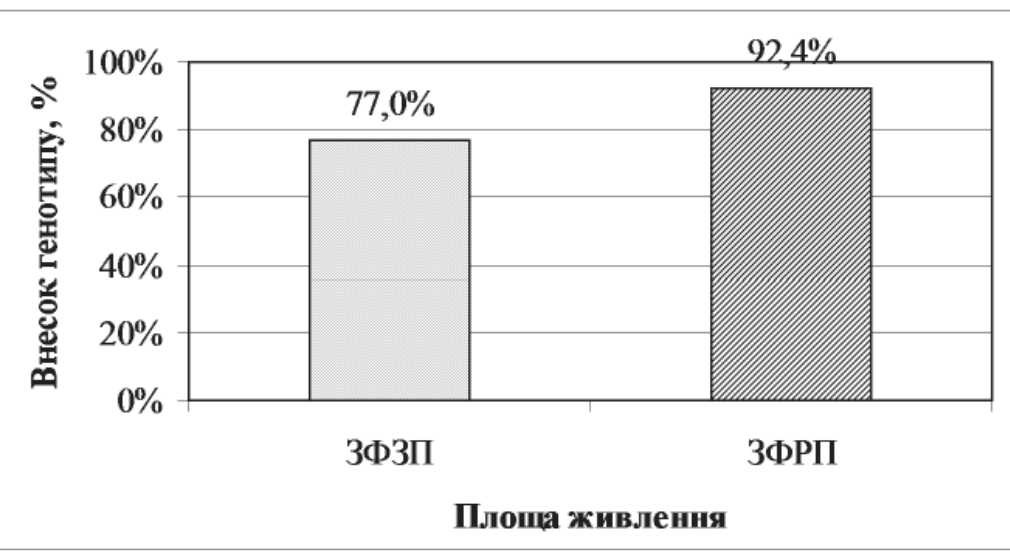

Рис. 2. Внесок генотипу гібрида у генотипну мінливість збору цукру на різних площах живлення

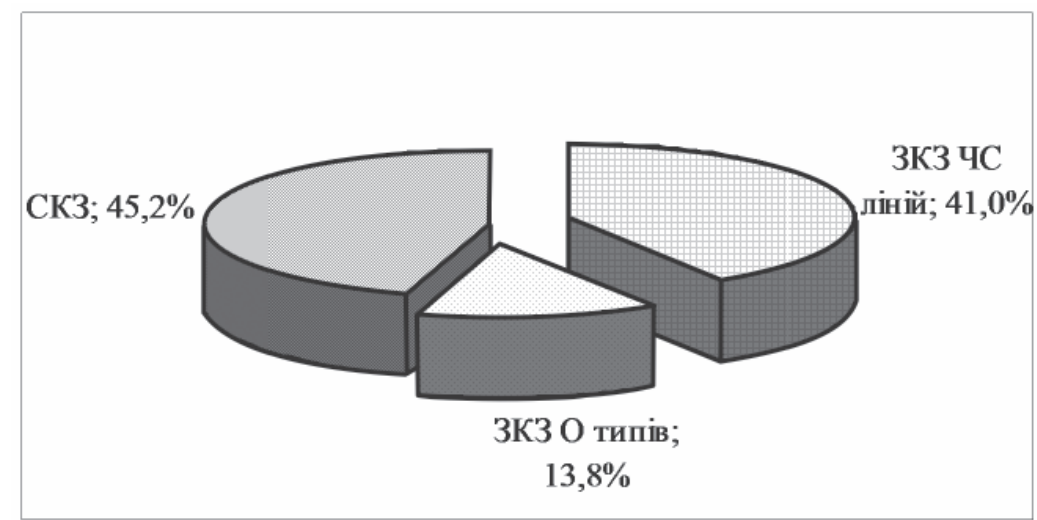

Рис. 3. Частки генотипної варіації компонентів ПСГ та їхньої взаємодії, ЗФРП

ЕФекти ЗКЗ і СКЗ за збором цукру ЧС ліній і О типів, ЗФРП

\begin{tabular}{|c|c|c|c|c|c|c|}
\hline \multirow{2}{*}{ ЧС лінії } & \multirow{2}{*}{$\begin{array}{c}\text { Ефекти } \\
\text { ЗКЗ ЧС } \\
\text { ліній }\end{array}$} & \multicolumn{5}{|c|}{ Ефекти СКЗ } \\
\hline & & От 1 & От 2 & От 3 & От 4 & От 5 \\
\hline 4C 1 & $1,23 *$ & $\#$ & $-0,01$ & $0,57^{*}$ & $-0,67$ & 0,12 \\
\hline $4 C 2$ & $-1,24^{*}$ & $0,96^{*}$ & $\#$ & $-1,06^{*}$ & $0,97^{*}$ & $-0,87^{\star}$ \\
\hline $4 C 3$ & $0,27^{*}$ & $-0,21$ & $1,43^{*}$ & $\#$ & $-0,97^{*}$ & $-0,25$ \\
\hline पC 4 & $-0,08$ & $-0,16$ & $-1,75^{*}$ & $0,58^{*}$ & $\#$ & $1,34^{*}$ \\
\hline $4 C 5$ & $-0,18$ & $-0,57$ & $0,81^{*}$ & 0,10 & $-0,34$ & $\#$ \\
\hline
\end{tabular}

* - достовірно високі ефекти комбінаційної здатності на 5\% рівні значущості.

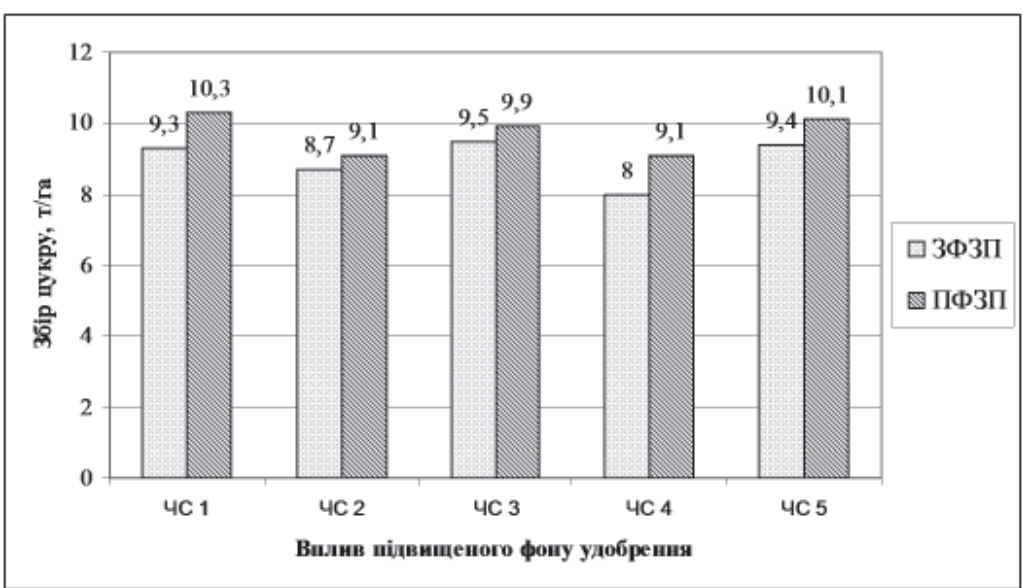

Рис. 4. Вплив підвищеного фону удобрення на збір цукру у ПСг (звичайна площа живлення)
ЧС 3 підтвердила свою оцінку $\left(+0,27^{*}\right)$ (табл. 2). Ці лінії $\in$ носіями цінних адитивних комплексів генів, що позитивно впливатимуть на прояв ознаки у гібридному генотипі.

Порівнюючи дані таблиць 1 і 2, можна стверджувати, що компоненти ПСГ ЧС 3/От 2 на обох площах живлення проявили істотно високий ефект взаємодії: на $3 П+1,00 *$, на РП $+1,43^{*}$. Аналогічно підтверджені оцінки неадитивної взаємодії генів у гібрида ЧС 4/От 5: на 3П $+1,42^{*}$, на РП +1,34*. У компонентів гібрида ЧС 2/От 1 також на різних площах живлення проявився подібний ефект СК3 - відповідно +0,82* (табл. 1) і 0,96* (табл. 2). Тобто, ці гібриди мали стабільно позитивну реакцію взаємодії компонентів незалежно від середовищного фактора.

Розширена площа живлення слугувала модифікувальним чинником для прояву неадитивних ефектів у комбінації ЧС 4/От 3, ЧС 1/От 3, ЧС 5/От 2, збільшуючи величину їхніх ефектів.

Підвищений фон звичайна площа. У цьому варіанті ПСГ, створені на основі п'яти ЧС ліній, показали вищий збір цукру, порівняно 3 варіантом ЗФЗП (рис. 4).

На рис. 4 видно, що у гібридів, створених на основі всіх ЧС ліній, на підвищеному фоні удобрення збір цукру збільшувався на 0,4...1,1 т/га (залежно від генотипу компонентів), тобто цей фактор мав істотний вплив на фенотипний прояв ознаки.

На розширеній площі спостерігалася аналогічна тенденція. Найкраще проявили себе гібриди, створені на основі ЧС ліній 1, 3 і 5.

Дисперсійний аналіз варіанта ПФЗП показав, що і гібриди, 
Реакція простих стерильних гібридів буряку цукрового за збором цукру на регульовані фактори середовища

і компоненти вносили істотний вклад як джерела дисперсії у фенотип гібридів. По гібридах $\mathrm{F}_{\text {факт }}=14,37>\mathrm{F}_{\text {теор }}=2,01$, по $4 \mathrm{C}$ лініях $\mathrm{F}_{\text {факт }}=24,98>\mathrm{F}_{\text {теор }}=2,69$, по O типах $\mathrm{F}_{\text {факт }}=7,09>\mathrm{F}_{\text {теор }}=2,92$, по взаємодії компонентів $\mathrm{F}_{\text {факт }}=12,66>\mathrm{F}_{\text {теор }}=2,09$. Відмінності між цими джерелами варіювання були високо достовірними, тому це дало змогу встановити частку впливу кожного з досліджуваних факторів на генотипну мінливість ознаки "збір цукру" у гібридів.

Як виявилося, у варіанті ПФЗП внесок О типів був найменшим і становив 7,8\% від усієї генотипної варіації, а ЧС ліній - майже у п'ять разів вищий, ніж для О типів (36,6\%). Однак частка неадитивної взаємодії генів навіть сумарно перевищувала адитивні ефекти та становила 55,6\% (рис. 5).

Аналіз ефектів ЗКЗ ЧС ліній показав, що комбінаційно цінними за ознакою "збір цукру" виявилися три лінії - ЧС $1(+0,60 *)$, ЧС $3\left(0,23^{*}\right)$ та ЧС $5\left(+0,37^{\star}\right)$ (табл. 3).

Високий позитивний ефект СК3 відмічено у парах ЧС 2/От 1 $\left(+1,19^{\star}\right)$, 4С 4/Oт $3\left(+0,85^{\star}\right)$ i чС 5/От $2\left(+0,93^{*}\right)$. Компоненти даних гібридів добре взаємодіють між собою, ефекти їхньої взаємодії вносять істотний вклад у фенотипний прояв збору цукру, що коливався у межах 9,7...10,9 т/га.

\section{Підвищений фон роз-} ширена площа. Гібридні комбінації на даному варіанті показали значну відмінність між собою як у ціломy $\quad\left(\mathrm{F}_{\text {факт }}=11,68>\mathrm{F}_{\text {теор }}=2,01\right)$, так і по компонентах: $\mathrm{F}_{\text {факт }}=3,44>\mathrm{F}_{\text {теор }}=2,69$ (для ЧС ліній); $F_{\text {факт }}=4,76>F_{\text {теор }}=2,92$ (для $О$ типів) та $\mathrm{F}_{\text {факт }}=16,15>\mathrm{F}_{\text {теор }}=2,09$ (для взаємодії батьківських форм).

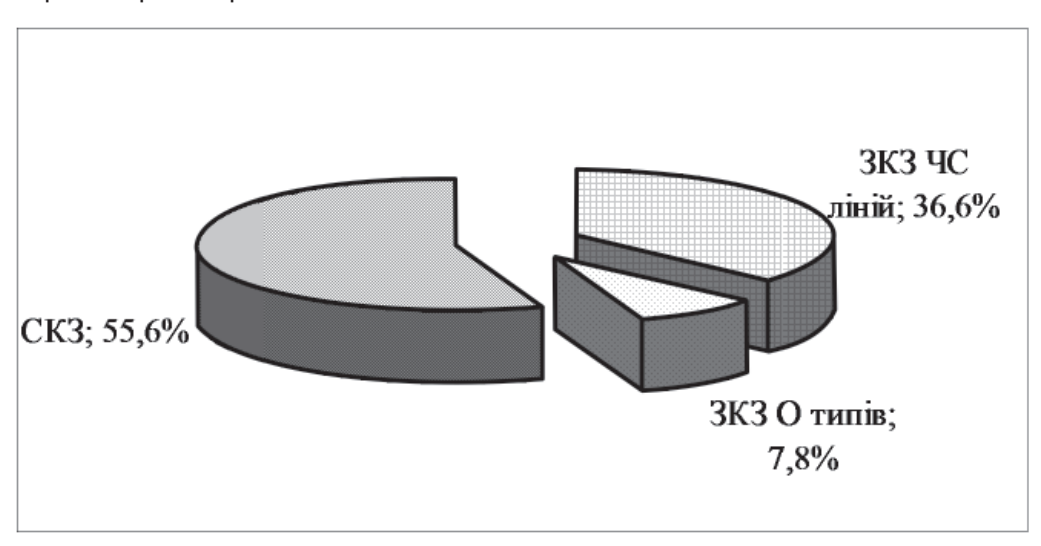

Рис. 5. Частки генотипної варіації компонентів ПСг та їхньої взаємодії за збором цукру, ПФЗП

Ефекти ЗКЗ і СКЗ за збором цукру ЧС ліній і О типів, ПФЗП

\begin{tabular}{|c|c|c|c|c|c|c|}
\hline \multirow{2}{*}{ ЧС лінії } & \multirow{2}{*}{$\begin{array}{c}\text { Ефекти } \\
\text { ЗКЗ ЧС } \\
\text { ліній }\end{array}$} & \multicolumn{5}{|c|}{ Ефекти СКЗ } \\
\hline & & От 1 & От 2 & От 3 & От 4 & От 5 \\
\hline पC 1 & $0,60^{*}$ & $\#$ & $-0,87^{*}$ & 0,17 & 0,25 & $0,45^{*}$ \\
\hline $4 C 2$ & $-0,63^{*}$ & $1,19 *$ & $\#$ & $-0,57^{*}$ & $0,37^{*}$ & $-0,99 *$ \\
\hline $4 C 3$ & $0,23^{*}$ & $0,33^{*}$ & 0,07 & \# & $-0,78^{*}$ & $0,38^{*}$ \\
\hline पC 4 & $-0,57^{\star}$ & $-0,10$ & $-0,60^{*}$ & $-0,85^{*}$ & $\#$ & $-0,15$ \\
\hline $4 C 5$ & $0,37^{*}$ & $-0,57^{*}$ & $0,93^{*}$ & $-0,69^{*}$ & 0,31 & \# \\
\hline
\end{tabular}

* - достовірно високі ефекти комбінаційної здатності на 5\% рівні значущості.

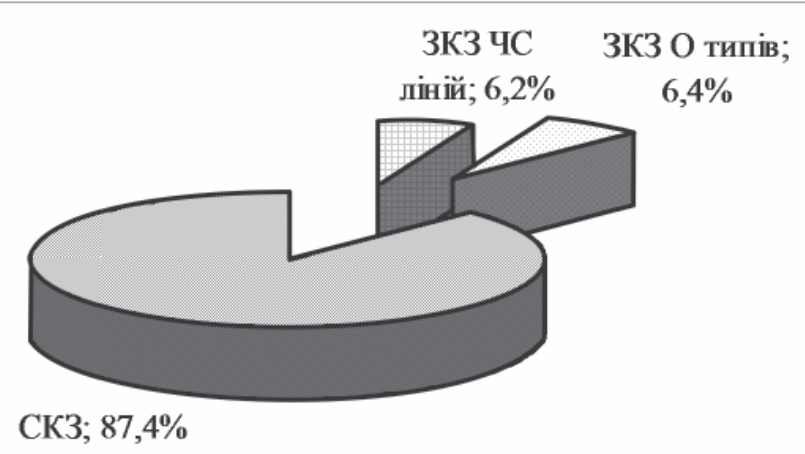

Рис. 6. Частки генотипної варіації компонентів ПСГ та їхньої взаємодії, ПФРП

Ефекти ЗКЗ і СКЗ за збором цукру ЧС ліній і О типів, ПФРП Таблиця 4

\begin{tabular}{|c|c|c|c|c|c|c|}
\hline ЧС лінії & $\begin{array}{c}\text { Ефекти } \\
\text { ЗК3 ЧС } \\
\text { ліній }\end{array}$ & \multicolumn{5}{|c|}{ Ефекти СК3 } \\
\hline & & От 1 & От 2 & От 3 & От 4 & От 5 \\
\hline 4С 1 & 0,05 & $\#$ & 0,37 & $-1,87^{*}$ & $0,78^{*}$ & $0,71^{*}$ \\
\hline 4С 2 & $-0,20$ & 0,02 & $\#$ & $0,91^{*}$ & $-0,46^{*}$ & $-0,47^{*}$ \\
\hline 4С 3 & $-0,03$ & 0,39 & $0,88^{*}$ & $\#$ & $-0,83^{*}$ & $-0,44^{*}$ \\
\hline 4С 4 & $0,36^{*}$ & $-0,57^{*}$ & $1,12^{*}$ & 0,11 & $\#$ & $-0,66^{*}$ \\
\hline 4С 5 & $-0,20$ & $-0,21$ & $-1,05^{\star}$ & $0,40^{*}$ & $0,86^{*}$ & $\#$ \\
\hline & & & & & & \\
\hline
\end{tabular}

* - достовірно високі ефекти комбінаційної здатності на 5\% рівні значущості. 
Реакція простих стерильних гібридів буряку цукрового за збором цукру на регульовані фактори середовища

Розширена площа живлення вплинула на структуру мінливості таким чином, що вплив ЗКЗ-ефектів понизився, а СКЗефектів підвищився.

Як виявилося, у варіанті ПФРП унесок адитивних генів компонентів гібридизації був набагато меншим (3К3 ЧС=6,2 \%; 3К3 От=6,4 \%), порівняно 3 неадитивними (87,4\%) (рис. 6).

Фактор "розширена площа живлення" вплинув також на диференціацію ліній по їхній 3КЗ і СК3 (табл. 4). Так, у варіанті ПФРП комбінаційно цінною виявилася лише лінія чС $4\left(+0,36^{*}\right)$. Високою та достовірною СКЗ характеризувалися компоненти шести гібридів: ЧС 1/От $4\left(+0,78^{\star}\right)$, ЧС 1/От 5 $\left(+0,71^{\star}\right)$, ЧС 2/От $3\left(+0,91^{\star}\right)$, ЧС 3/От $2\left(+0,88^{*}\right)$, पС 4/От 2 $\left(+1,12^{*}\right)$ та ЧС 5/От $4\left(+0,86^{*}\right)$.
Компоненти $з$ достовірними низькими (від'ємними) ефектами СКЗ селекційного значення не мають, тому немає сенсу їх аналізувати. А вищезазначені гібридні комбінації, у яких взаємодія компонентів - ЧС ліній і О типів була істотно високою, характеризувалися збором цукру, що перевищує 10,0 т/га. Значення цього показника були високими і незначно коливалися залежно генотипу від 10,07 до 10,63 т/га.

Висновки. На основі вищевикладених експериментальних даних можна стверджувати наступне:

- підвищений фон живлення та розширена площа $\epsilon$ модифікувальними факторами середовища, які спричиняють експресію комбінаційної здатності за ознакою «збір цукру»;
- за розширеної площі живлення повніше розкриваються генотипні особливості простих стерильних гібридів;

- підвищений фон живлення позитивно впливає на збір цукру ПСГ. У детермінації цієї ознаки на даному фоні переважаючу роль відіграють ефекти неадитивної взаємодії генів компонентів;

- кращими за ЗКЗ ЧС лініями на звичайному фоні живлення виявилися ЧС 1, ЧС 3 і ЧС 5;

- на обох площах живлення сталість неадитивних ефектів генів проявили комбінації 4С 3/От 2 (розширена площа) і чС 2/От 1 (звичайна площа);

- у кращих гібридних комбінацій у всіх варіантах збір цукру перевищує 10,0 т/га, що $\epsilon$ наслідком упливу як генотипу, так і середовищних чинників на вияв фенотипу.

\section{ВИКОРИСТАНА ЛІТЕРАТУРА}

1. Кильчевский А.В. Экологическая селекция растений / А.В. Кильчевский, Л.В. Хотылева. - Минск: Технология, 1997. - 372 с.

2. Borojtvic S. Ideotiypes for high produktivity, perfomance stability and adaptation / S. Borojevik // Proc. 2 - nd Inter. Winter Wheat Conf. Zagreb, 1975. - P. 45-59.

3. Мазлумов А.Л. Селекция сахарной свеклы / А.Л. Мазлумов - М.: Колос, 1970. - 207 с.

4. Грицык Н.С. Методы создания и оценки линий опылителей по комбинационной способности на Верхнячской ОСС / Н.С. Грицык // Достижения и перспективы в селекции сахарной свеклы. - Киев: ВНИС, 1987. - С. 92-95.

5. Методика исследований по сахарной свекле. - К.: ВНИС, 1986. - 292 с.
6. Савченко В.К. Метод оценки комбинационной способности генетически разнокачественных наборов растительных форм / В.К. Савченко // Методики генетико-селекционного и генетического экспериментов. - Минск: Наука и техника, 1973. - C. 48.

7. Грицык Н.С. Многофакторные испытания / Н.С. Грицык // Сахарная свекла. - 1987. - № 7. С. 36-37.

8. Вольф В.Г. Методические рекомендации по применению математических методов для анализа экспериментальных данных по изучению комбинационной способности / В.Г. Вольф, П.П. Литун - Харьков, 1980. -74 c.

9. Доспехов Б.А. Методика полевого опыта / Б.А. Доспехов - М.: Колос, 1979. - 375 с. 